\title{
The LithicUB project: A virtual lithotheque of siliceous rocks at the University of Barcelona
}

\author{
Marta Sánchez, Mar Rey, Núria Rodríguez, Azucena Casado, Bárbara Medina \\ and Xavier Mangado
}

Seminari d'Estudis i Recerques Prehistòriques, Dept. Prehistòria, Història Antiga i Arqueologia, Universitat de Barcelona, Spain. Email: Sánchez: martasanchezdelatorre@ub.edu; Rey: mreysole@gmail.com; Rodríguez: nuria.rb.arq@gmail.com; Casado: azucenacf@gmail.com; Medina: barbaramedina79@ hotmail.com ; Mangado:mangado@ub.edu

\begin{abstract}
:
The LithicUB project began in 2009 with two main objectives. The first objective was to make available to the scientific community the description and classification of a set of siliceous rocks that had been recovered from different surveys. The second to make public the lithotheque as a useful tool for archaeological research, related to the procurement and management of lithic raw materials in Prehistory. Thanks to several research projects that have been carried out, the number of samples is steadily increasing and diversifying, including siliceous rocks collected in Spain, Portugal, France, Jordan and Israel.
\end{abstract}

Keywords: siliceous rocks, Charente Basin, Iberian Peninsula, Azraq Basin, Petroarchaeology

\section{Résumé:}

Le projet LithicUB a commencé en 2009 avec deux objectifs principaux. Le premier était de mettre à disposition de la communauté scientifique la description et la classification d'un ensemble de roches siliceuses qui avaient été récupérées après de nombreuses prospections. Le second objectif était de créer une lithothèque publique qui pouvait être un outil utile pour la recherche archéologique, notamment liée à l'acquisition et la gestion des matières premières lithiques en Préhistoire. Grâce à plusieurs projets de recherche qui ont été effectués pendant des années, le nombre d'échantillons est en constante augmentation et on y compte des roches siliceuses recueillies en Espagne, Portugal, France, Jordanie et Israël.

Mots-clé: Roches siliceuses, bassin de la Charente, Peninsule ibérique, bassin d'Azraq, pétroarchéologie.

Published by the School of History, Classics and Archaeology, University of Edinburgh ISSN: 2055-0472. URL: http://journals.ed.ac.uk/lithicstudies/

This work is licensed under a Creative Commons Attribution 2.5 UK: Scotland License. 


\section{Introduction}

In the late 1980s several problems related to the value of prehistoric raw material identification systems and their diffusion and circulation emerged. The need solve these new issues led many researchers to initiate a series of geological surveys and fieldwork in order to locate or detect these raw materials, most of which were siliceous, which would have been susceptible to use in different periods of prehistory. This scientific curiosity, first raised in France and extended then to the Iberian Peninsula, turned to more specific aspects such as those of an economic and technological nature, and later brought on the need to create reference collections (Mangado et al. 2010). Siliceous rocks could then be described and analysed in a multi-scale approach that could generate knowledge about the outcrops and answers to some questions such as procurement, management and circulation of lithic raw materials during prehistoric times.

Taking into account that the petroarchaeological research involves thorough fieldwork and the compilation of many samples, the creation of a lithotheque becomes is a useful tool that allows researchers to save unnecessary fieldtrips and optimises financial resources. Thus our "LithicUB" project takes place in this context.

The financial support of the Intensification of the Research General Program at the University of Barcelona allowed us to create the LithicUB. The project began with two main objectives: first, to classify, organise, describe and manage a set of siliceous rocks that had been recovered from different surveys and to make it available to the scientific community as well as students and the general public interested in this subject. The second objective, closely related to the first, was to become a support tool to facilitate, simplify and contribute to archaeological research.

Our lithotheque can be consulted at the laboratory of Prehistory and Archaeology at the Faculty of Geography and History from the University of Barcelona, but it is also available on a website version to facilitate a distant consultation by any researcher from any location in order to assess its potential before a possible visit and a direct hand-on consultation at our institution.

At the beginning of the project, most of our samples were from various areas of the Catalan region, and to a lesser extent from France and Portugal. Today, thanks to different research projects carried out in recent years, the number of samples has increased and diversified, including specimens from other areas of the Iberian Peninsula (Pyrenees, Western Iberia, Southern Catalonia and Northern Castellón). Moreover, the participation in various other projects has enabled us to include samples from Jordan and Israel. Within the framework of these projects, it has also been possible to study and describe siliceous rocks from the Charente lithotheque, descriptions that are now included on our website.

This paper aims to present the LithicUB project, its organisation, content, the web version and how this organisation can contribute to improve archaeological research, giving a special emphasis to the latest research carried out.

\section{Lithotheque organisation}

\subsection{The laboratory organisation}

The lithotheque available in our laboratory includes 383 samples that correspond to 107 outcrops. These samples are stored in boxes, which are placed on shelves. Each box, identified with a label, is grouped following geographical codes. Those labels indicate key data, such as the geological formation, the outcrop GPS location, the name of the surveyor, if a thin section was performed or not, and the archaeological sites related to those samples (Figure 1). 

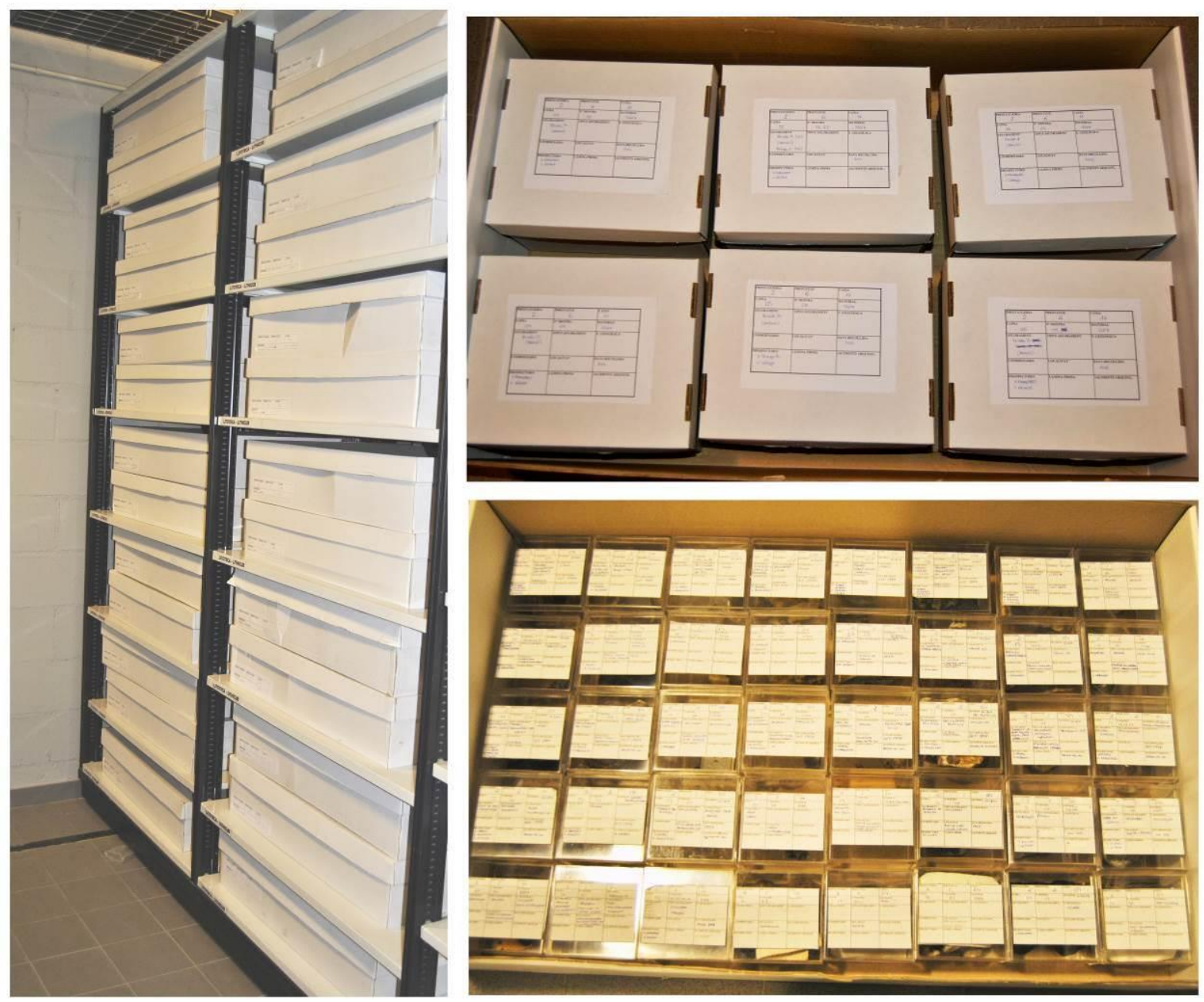

Figure 1. Lithotheque organisation at the laboratory.

\subsection{The web organisation}

The physical lithotheque is attached to a virtual one, which is available on the Internet since 2009. There, the user can view all the existing samples in the physical lithotheque. The purpose of the virtual lithotheque is to ease the consultation of the physical collection and all the research done. The goal is to promote the study and research of prehistory, with the data obtained in this project. The virtual lithotheque has the following features:

- Consult collection samples, with the following information (Figure 2):

- Macroscopic and microscopic description

- A wide variety of photographs of each sample

- Detailed information about the material, geological formation and the outcrop from which it was extracted

A glossary of technical terms and a related bibliography

- Advanced search of the samples, outcrops and geological formations, to facilitate the searches for samples with specific characteristics.

- Location of the outcrops, integrated in Google Maps.

- Option to print or export the descriptions of the samples in PDF format.

- Administration panel, where authorised members can manage all the website content, including the existing samples, the images and the bibliography. 


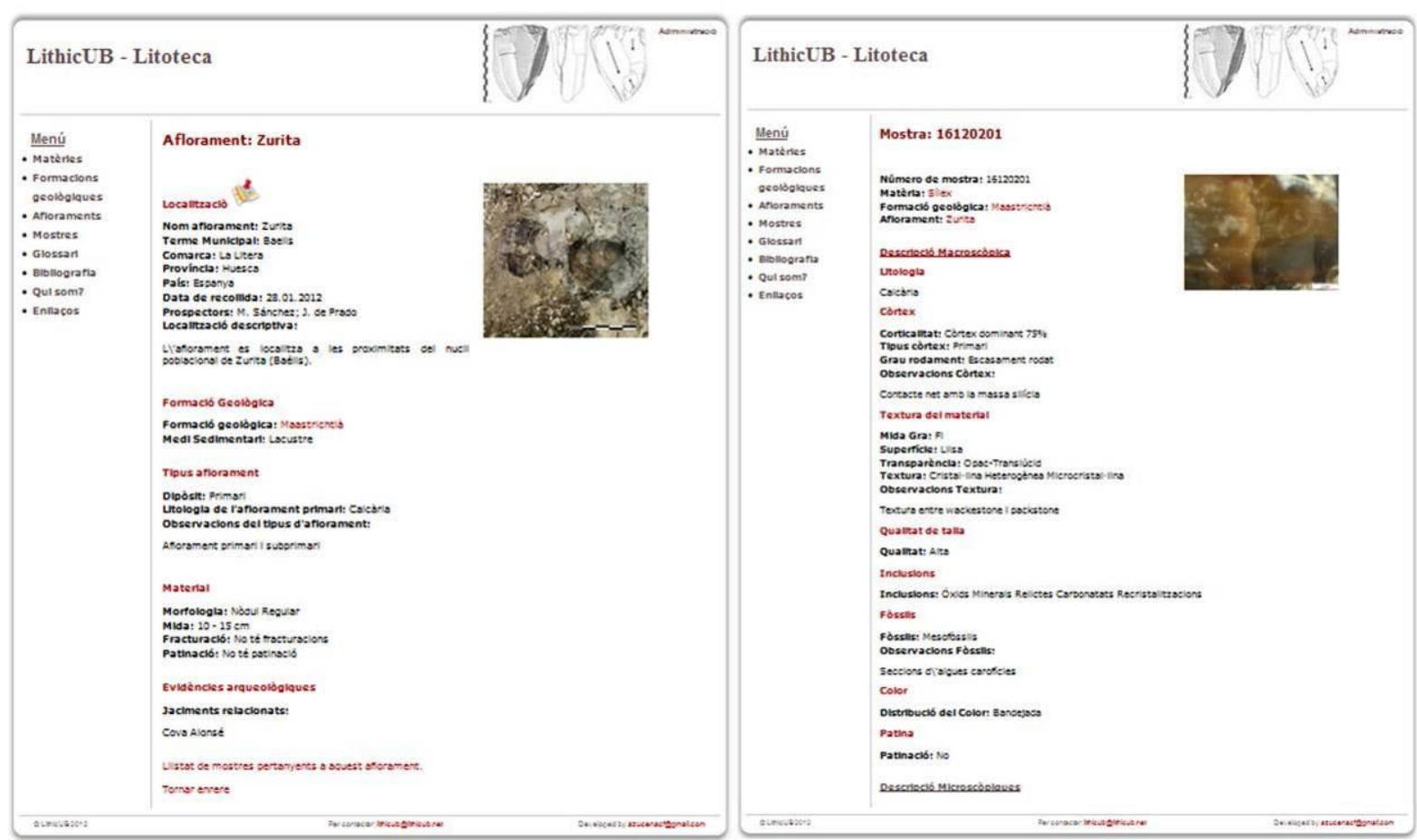

Figure 2. Outcrop description and macroscopic description that can be consulted on our web page.

The entire site was to built using an open source software and it has been developed in object-oriented PHP (Zend Framework) for the back-end, using Javascript for the data validation. Data are stored using MySQL as the relational database management system. Moreover, several existing third party applications were integrated to enhance the functionalities of the website, such as Google Maps API, DoomPDF or TinyMCE, among others. You can visit the collection at: $w w w$. lithicub.net.

\section{Methodology}

The methods and techniques implemented to describe and classify the lithotheque samples are the same as the ones applied in Geology, especially in Petrology. As most of the samples are chert, which belongs to the sedimentary rock group, both methodological and descriptive terms applied correspond to those used to describe and classify these rocks.

Basically three scales of analysis are applied: visu, macroscopic and microscopic. The visu analysis is the first approach, which is usually done in the field and then repeated in the laboratory. This is a first contact with the sample and it leads us to describe those characteristics observable with the naked eye. To expand, refine and correct this first approach, we perform a macroscopic description of the sample with the aid of a binocular microscope. This technique, being non-destructive and low-cost, provides a wealth of information about the rock allowing a fairly complete description of the sample. After this, we select multiple samples from the same rock type to create thin sections that will be analysed using an optical polarised microscope. This latter analysis allows us to complete the characterisation and the macroscopic analysis. Data obtained after this characterisation process should be sufficient to make an initial comparison between geological samples and archaeological ones, making it possible in some cases to determine the geological and geographical origin of the archaeological assemblage (Mangado 2004).

However, we must take into account that these three approaches are qualitative analysis techniques based on visual observation and therefore are not exempt from the subjectivity of the observer, who uses his or her own experience to perform the determination of either 
component. In this sense, the creation of regional lithotheques represents a major step in creating searchable databases and making easier the work of researchers, thus saving time and economic resources. Furthermore, the relationship between different lithotheques and researchers working in the field of Petroarchaeology, can mitigate the effects of subjectivity in the description, through close collaboration leading to the homogenisation of the criteria used (Mangado 2004; Mangado et al. 2010).

\section{Collections}

The Siliceous Rocks Lithotheque at the University of Barcelona consists of a series of collections from many areas around the world (Figure 3). All of them have an archaeological background, as they are directly linked to projects of this discipline. Those projects desire to locate the lithic source areas that could have been used by the groups that occupied those sites thousands years ago.

Here we present the main regions studied, the archaeological projects with which they are related, and the formations and samples linked to each reference collection.

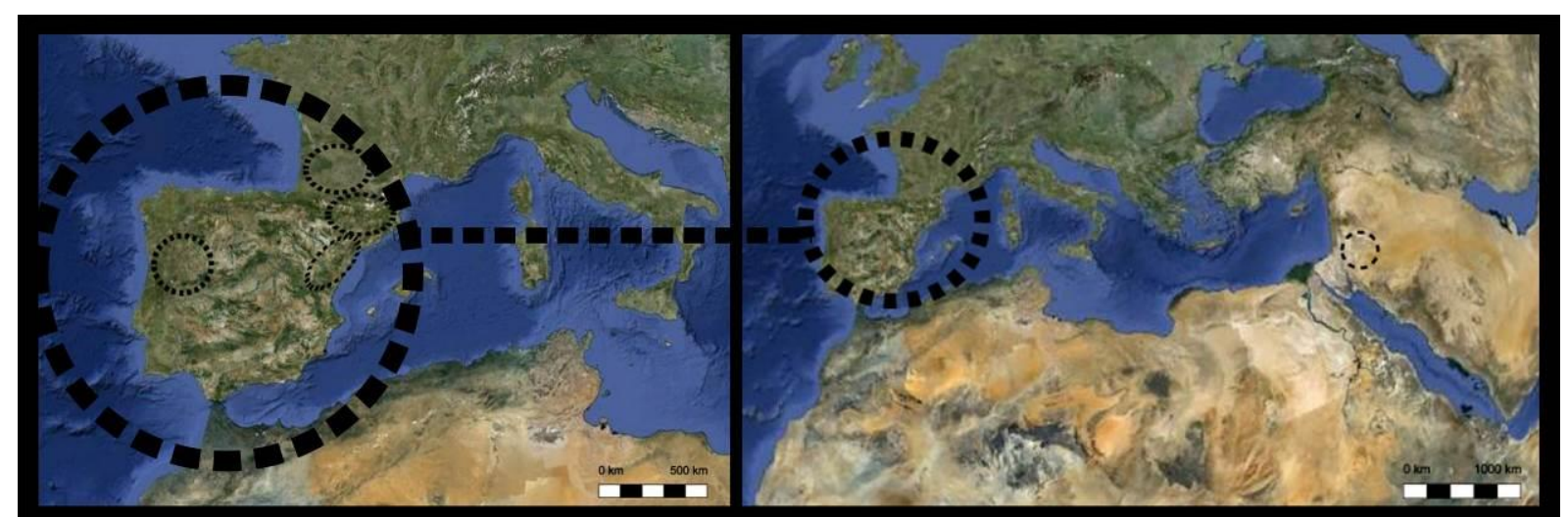

Figure 3. Map with the geographical areas studied. Source: Google Earth modified.

\subsection{Western Iberia}

Our research in this area was directly related to the open air archaeological sites located next to the Foz Côa (Portugal) Palaeolithic engravings (Figure 4).

In 1999, the late Magdalenian site Cardina I (Santa Comba, Tras-os-Montes, Portugal) was included in this project through collaboration between the Vale do Côa Archaeological Park (PAVC) and Seminari d'Estudis i Recerques Prehistòriques (SERP) of the University of Barcelona (Mangado, 2005). The industrial complex analysed was polilithologic, with a wide variety of lithologies representing different origins such as quartzite, quartz and other rocks, but where chert appeared as only a few samples (1\% of the total) (Aubry et al. 2012).

Our research is based, on the one hand, on the geological survey of vast territories likely to contain geological formations with chert (Lias, Cretaceous, Jurassic, Miocene) in western Iberia and, on the other hand, petroarchaeological analysis of the cherts recovered at the different sites of the Côa Valley, thus establishing the importance of this resource at the regional level.

Our aim was to establish the likely source areas of lithic raw material that was exploited by the inhabitants of the lower basin of the Côa and particularly Cardina I. The main interest of this analysis lies in the absence of such material in the lithological context of the area. 


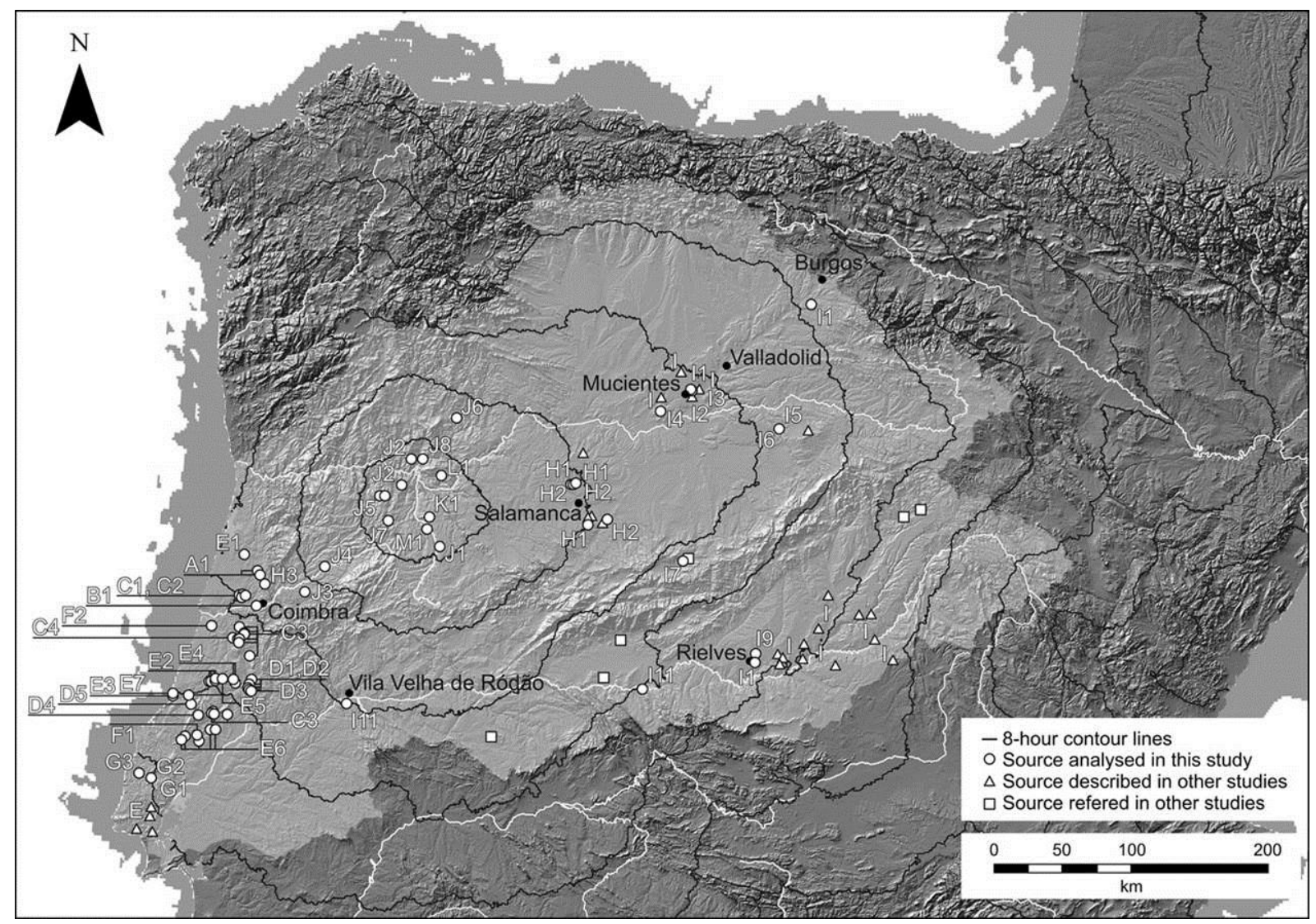

Figure 4. Siliceous rocks materials available between the Douro and Tagus basins with time costs estimated from a mean centre in the Côa Valley area. Source: Aubry et al. 2012.

\subsection{Iberian Range and Catalan Coastal Range}

The Iberian Range and the Catalan Coastal Range are located in the eastern part of the Iberian Peninsula, limited on the east by the Iberian Massif to the Mediterranean. The study area is bounded to the Levantine sector of the Iberian Range (located at the SE of the Castilian - Valencian Branch), which extends from the north of the middle of the Jucar River to the east of Maestrazgo. The materials that emerge in this sector are mainly Mesozoic although quite often we can find Tertiary or Quaternary materials.

We focused our interest on this area because we carried out the study of raw materials used to make the lithic industry collected at Roureda Rockshelter (Vilafranca, Els Ports, Castellón). This is a small cavity, 6 meters in length and 2 meters in depth, located about 1150 m. a.s.l., in which only one occupation level (Level II) provided a radiocarbon date from charcoal of 11,350 $\pm 70 \mathrm{BP}(13,360-13,090 \mathrm{cal}$. BP, Beta - 244009), ascribing the site to the ancient Epimagdalenian (Roman 2010).

Between 2010 and 2013 we conducted two surveys that covered different areas of the Maestrazgo and where we identified three chert outcrops respectively. In the first outcrop, located in the conglomerates of the Font de la Salut (Traiguera, Castelló), we collected two chert samples and in the second outcrop (Figure 5), located in Fortanete (Teruel), we took two samples. In 2013, we conducted the second survey, covering the area of Mas del Pinar (Vilafranca, Els Ports) and we collected three samples of different varieties of cherts.

These seven samples were described macroscopically and are currently in the process of being analysed microscopically. In a few weeks it will be possible to consult them on our website. Coming soon we will expand the collection of samples from this area because it is being pursued as part of a doctoral dissertation concerning the availability of siliceous rocks and their supply by the prehistoric communities in the area. 


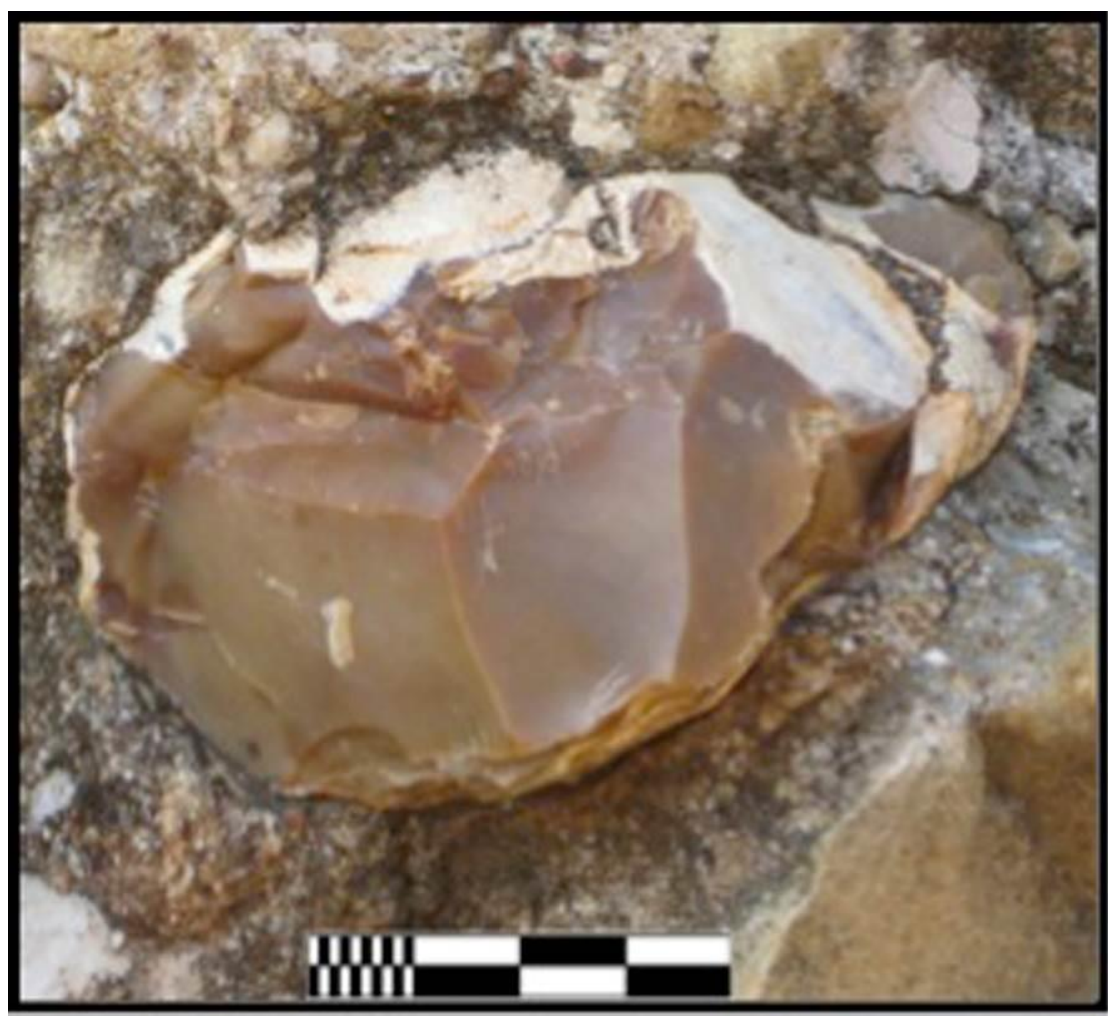

Figure 5. Chert sample from Font de la Salut Conglomerates outcrop (Traiguera, Castelló).

\subsection{The Pyrenean Area}

The Pyrenees are one of the most impressive mountain ranges in the south-western part of Europe. Administratively belonging to three European countries (France, Spain and Andorra), they stretch from east to west crossing the isthmus that connects the Iberian Peninsula with Europe. With a length of about $425 \mathrm{~km}$ and a maximum area of $19000 \mathrm{~km}^{2}$, this mountain range has summits above 3000 metres a.s.l.

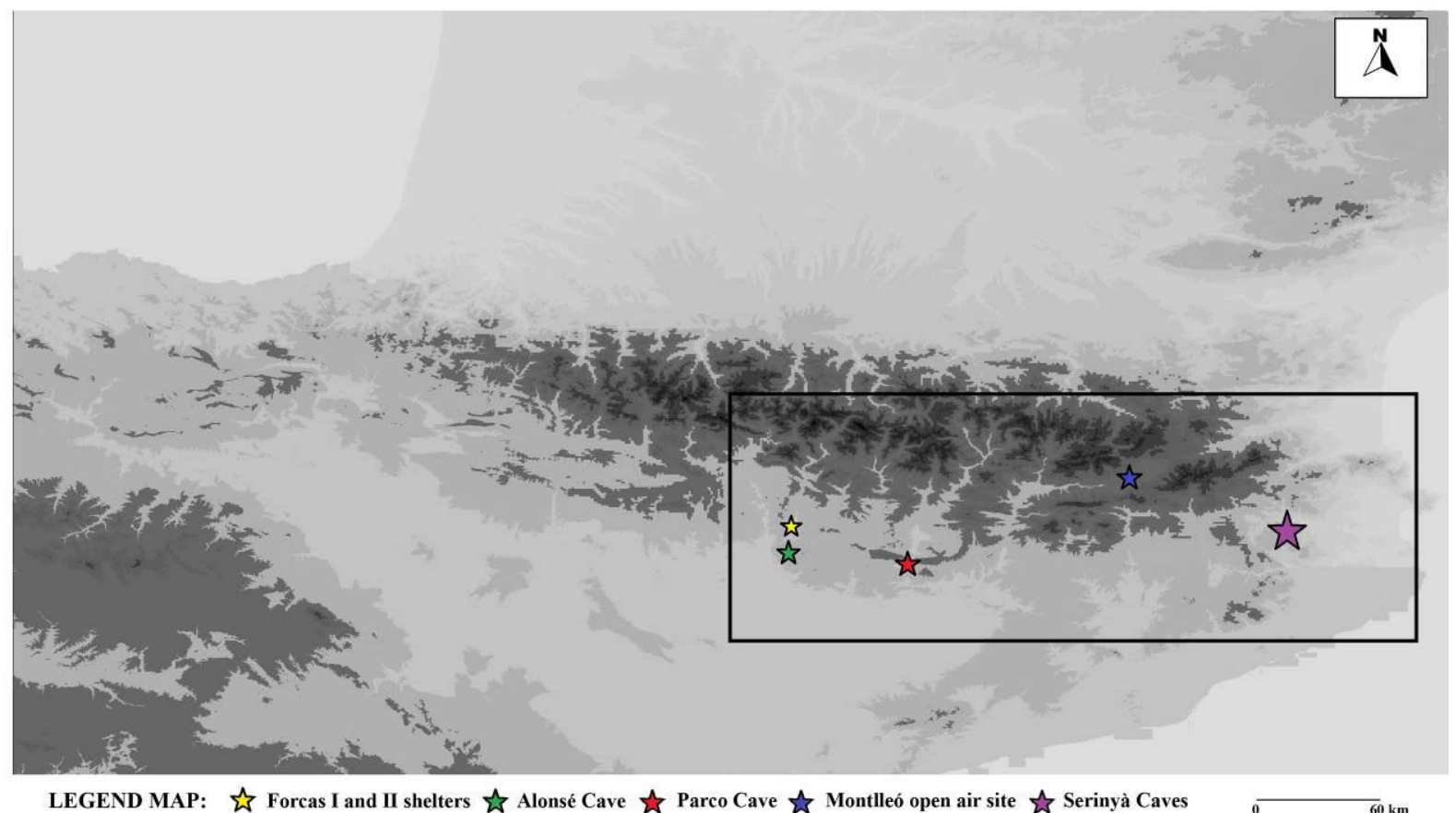

Figure 6. Map of the archaeological sites that are related with the Pyrenees collection. 
Our studies on the Pyrenees have focused until now on the central-east side, related to the existence of several archaeological projects in this area. In that way, a team from the University of Barcelona studied the human population on the southern side of the Pyrenees during the Upper Palaeolithic. Moreover, another group from the University of Zaragoza analysed the prehistoric groups that settled in the Central Pyrenees. In addition, the University of Girona has led for decades a project that seeks to understand the human population during the Palaeolithic in the most eastern side of the Pyrenees.

The number of archaeological sites that have been excavated and the desire to learn more about the lithic provisioning strategies carried out by prehistoric groups led to the creation of the lithic collection, which continues to increase even today (Figure 6). A total of eight geological formations have been surveyed, including a set of 47 siliceous rock outcrops that have been documented. The number of analysed samples comes to 150 units, 73 of which are available on the website and the rest are currently being processed.

\subsection{Charente Basin}

The Charente basin is in the French department of La Charente, located in the southwest of France (Poitou-Charentes region). It reaches an altitude of 250-300 meters and is mainly composed of a great variety of sediments, deposited from the Jurassic to the Oligocene. This basin has been studied since the 80's due in part to studies like those of Séronie-Vivien about the availability of cherts in the area (Séronie-Vivien \& Lénoir 1987). From 2002 on, thanks to the research project led by Anne Delagnes (UMR5199 - Pacea, IPGQ, University Bordeaux I) and the PhD research of Seong-Jin Park (Institute of Cultural Properties, Hangyang University, South Korea) on lithic production and circulation of raw materials at the Middle Palaeolithic site of La Quina, new surveys were undertaken in the area. All of the surveys recovered a total of 183 samples from 123 different outcrops belonging to different stages of the Lower and Middle Jurassic and Upper Cretaceous (Figure 7).

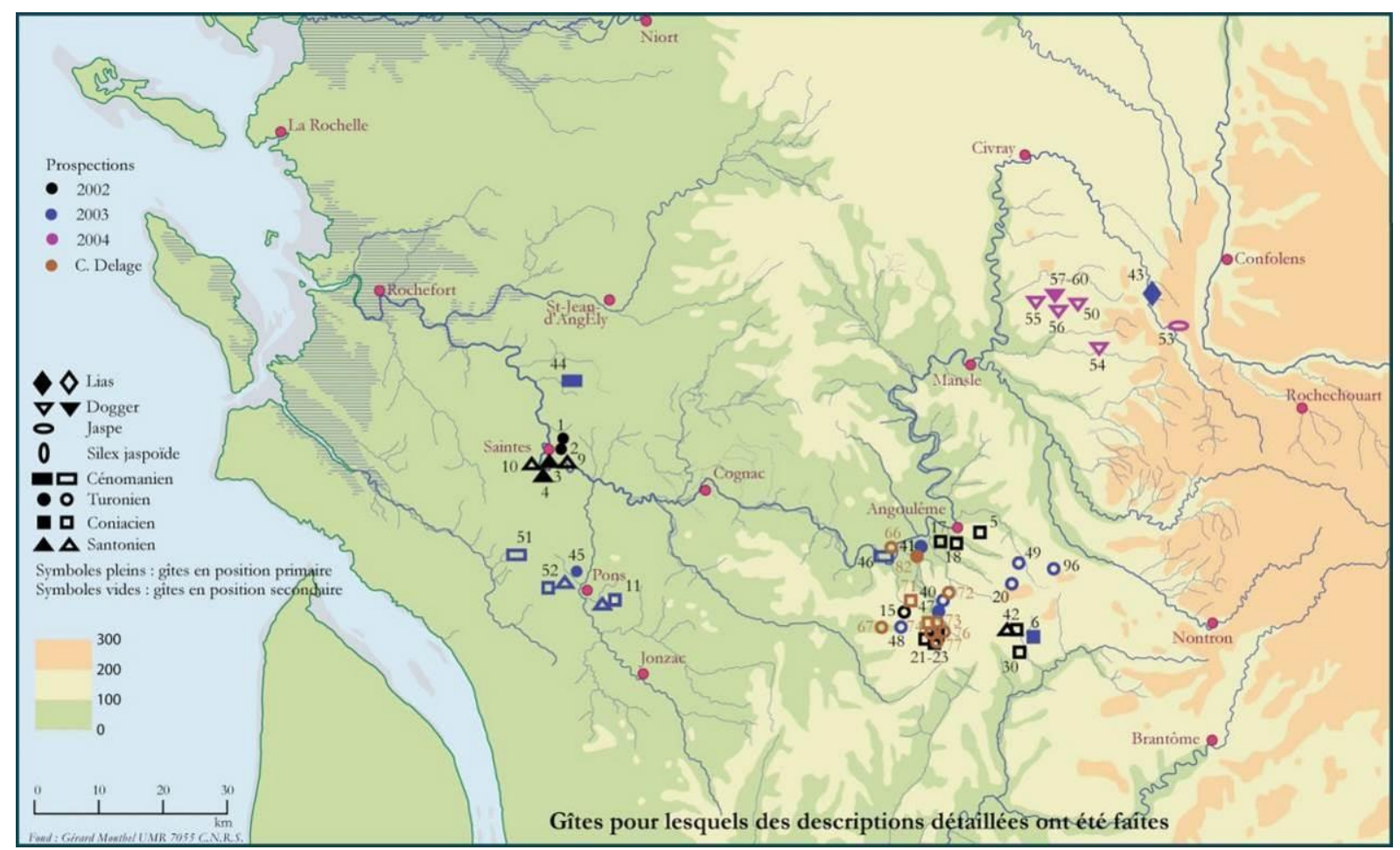

Figure 7. Geological map of the Charente Basin and the surveys conducted. Source: Féblot-Augustins \& Parks 2010. 
From this point, in 2005, Delagnes, Féblot-Augustins and Park founded the Charente Regional Lithotheque, which represents the entire chert varieties available in that territory. For more information please consult the following website: http://www.alienor.org/ARTICLES/lithotheque/index.htm.

Simultaneously, Christophe Delage conducted his own survey of the area focusing on the Cretaceous deposits south of Angoulême, in relation to the Magdalenian site of La Chaire-àCalvin (Mouthiers-sur-Boëme). In 2010, he gave part of his own Lithotheque Collection (56 samples from 24 outcrops of the Cenomanian and Turonian) to the LithicUB project and we did the petroarchaeological study, which is available on the website. In the future, we would like to continue with this study and analyse the provenance of the stone tools recovered at the Magdalenian site of the La Chaire-à-Calvin stone tools for which, the geographical and geological origin is still unknown.

\subsection{Azraq Basin}

In 2006 a new archaeological project started, directed by Jay Stock, Lisa Maher and Tobias Richter in the Azraq Basin (Jordan). This area presents numerous archaeological sites from the Lower Palaeolithic to the Late Epipalaeolithic. At the same time as the excavation at Kharaneh IV was taking place, in May-June 2010, some of us (X. Mangado with C. Delage) conducted a geo-archaeological survey focusing on the recognition and sampling of cherts in sedimentary outcrops.

Besides alluvial and fluviatile deposits dated from the Miocene-Pleistocene to recent times, three in situ carbonate rock formations are present in the Kharaneh area:

- Muwaqqar Chalk-Marl Formation

- Umm Rijam Chert-Limestone Formation

- Wadi Shallala Chalk Formation

The Muwaqqar Chalk-Marl Formation (MCM) represents the oldest stratified rock formation in the area. It has been dated to the Upper or Late Cretaceous. Until now, we have localised seven chert outcrops in the Kharaneh Area, and at the moment, two of these outcrops (MCM3 and MCM4) and the macroscopic and microscopic description of related chert samples can be consulted in our virtual lithotheque.

The Umm Rijam Chert-Limestone Formation (URC) corresponds to a sequence of sedimentary rocks characterised by limestone and chalk, associated with numerous chert nodules and beds, which comfortably overlies the Muwaqqar Chalk Marl Formation (Figure 8). Based on the specific composition of microfossils (e.g. planktonic and benthic foraminifera), geologists have proposed a Lower or Middle Eocene age for this formation (Figure 9).

The soft-weathering chalks of the Wadi Shallala Chalk Formation (WSC) are easily recognisable above the hard limestone beds of the URC formation. According to geologists, this formation yields very limited exposures of about 10-20 m thick in the area. These might correspond to the lowest member of this formation. Geologists attribute this formation to the Middle to Late Eocene, based on the presence of specific radiolaria, ostracods and foraminifera.

As a preliminary step, a total of 104 samples were collected in an area of $50 \mathrm{~km} \mathrm{x} 60 \mathrm{~km}$ around Kharaneh IV. We have analysed the samples recovered in two outcrops of the Muwaqqar Chalk-Marl Formation (MCM 2 and MCM 3), seven outcrops of the Umm Rijam Chert-Limestone Formation (URC 5, URC 19, URC 23, URC 32, URC 41, URC 44 and URC 62) and five outcrops from the Wadi Shallala Chalk Formation (WSC 1, WSC 3, WSC 6, WSC 8 and WSC 12). 


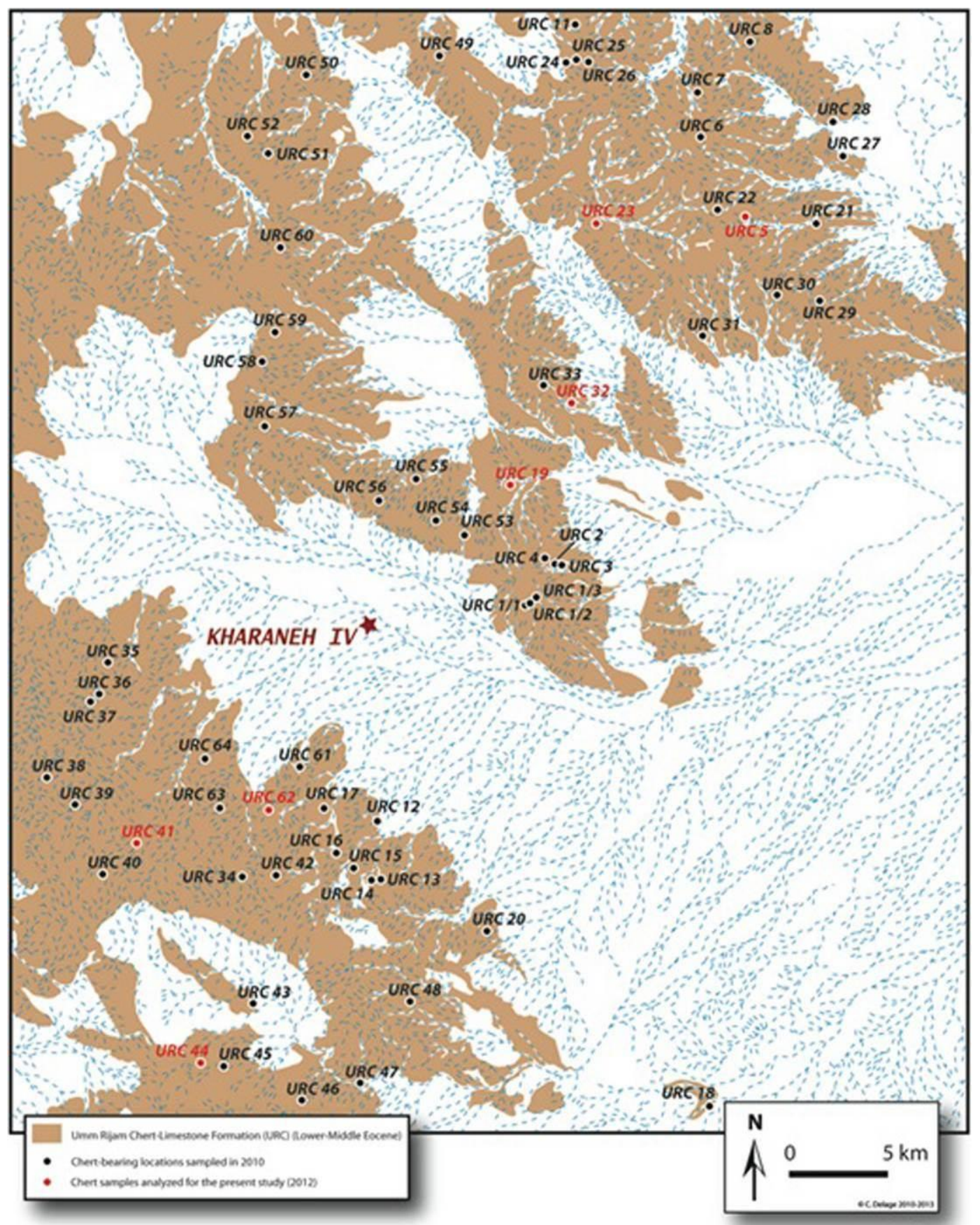

Figure 8. Samples analysed from URC that can be consulted at the moment in our virtual lithotheque (in red colour). Map created by C. Delage
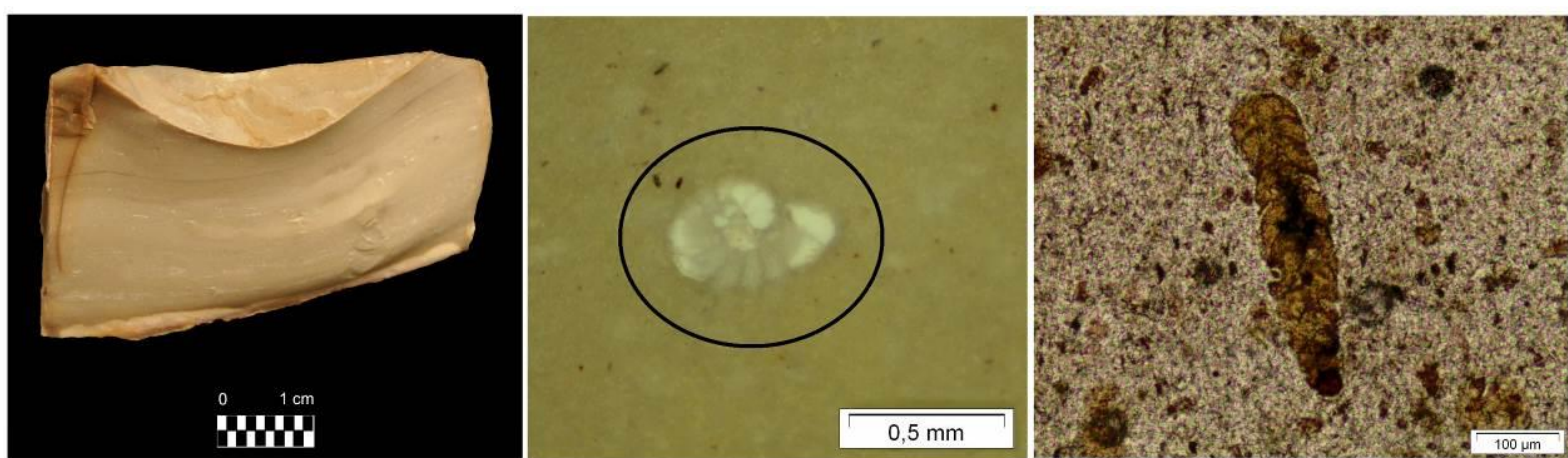

Figure 9. Visu view (left), macroscopic view (centre) and microscopic view (right) of a URC Formation chert. 


\section{Future lines of research}

Our future research will focus on two points. On the one hand, we will enlarge the number of samples from the previously studied zones. On the other hand, we will include and carry on the characterisation of Near Eastern samples from the Eocene of Israel. The first phase of fieldwork has been undertaken in collaboration with Christophe Delage. The aim of our future work in this area is to develop a reference collection of siliceous rocks for the Near East region, Jordan and Israel, to be used in the study of mobility patterns of ancient populations in that area.

\section{Acknowledgements}

The research presented in this paper has been supported by project PGIR08/09 of the University of Barcelona, project HAR 2011-26193 of the Spanish Government and SGR 2009-01145 from the Government of Catalonia. We would like to express our gratitude to C. Delage for the English revision of this article.

\section{References}

Aubry, T., Luis, L., Mangado, X. \& Matias, H., 2012, We will be known by the tracks we leave behind: exotic lithic raw materials, mobility and social networking among the Côa Valley foragers (Portugal). Journal of Anthropological Archaeology, 31: p. 528-550. doi: 10.1016/j.jaa.2012.05.003

Féblot-Augustins, J. \& Parks, S. J., 2010, Circulation des matières premières et modalités d'exploitation territoriale au Paléolithique moyen récent dans le bassin de la Charente. In: Settlement Dynamics of the Middle Paleolithic and Middle Stone Age, (Conard, N.J. \& Delagnes, A., Eds.) Kerns-Verlag, Tübingen: p. 397-426. (in French) ("Raw material circulation and territory exploitation modalities in the Charente Basin during the Middle Paleolithic")

Mangado, X., 2004, L'arqueopetrologia del sílex. Una clau per al coneixement paleoeconòmic i social de les poblacions prehistòriques, Societat Catalana d'Arqueologia, Barcelona, 116 p. (in Catalan) ("The petroarchaeology of chert. A key to understanding the social and paleoeconomical knowledge of prehistoric groups")

Mangado, X., 2005, La caracterización y el aprovisionamiento de los recursos abióticos en la Prehistoria de Cataluña: las materias primas silíceas del Paleolítico Superior Final y el Epipaleolítico, BAR International Series 1420, Oxford, 205 p. (in Spanish) ("Characterisation and abiotic resource provisioning in Prehistory of Catalonia: siliceous raw materials from the Final Upper Paleolithic and the Mesolithic")

Mangado, X., Medina, B. \& Casado, A., 2010, LITHIC_UB: Un projet de lithothèque à l'Université de Barcelone. Les cahiers de Géopré 1, Electronic publication: p. 51-55. (in French) ("LITHIC_UB: A lithotheque project at the University of Barcelona")

Mangado, X., Morales, J.J., Oms, F.X., Rey, M. \& Sánchez, M., 2012, Estudio de los restos líticos de la Cova Colomera (prepirineo de Lleida) entre 5220 y 1660 cal BC. Análisis arqueopetrológico de las materias primas silíceas y posibles áreas de captación. Rubricatum 5, Actes del Congrés Internacional Xarxes al Neolític: p. 155-161. (in Spanish) ("The study of lithic tools from Colomera Cave (Lleida Prepyrenees) between 
5,220 and 1,660 cal BC. Petroarchaeological analysis of siliceous rocks and potential catchment areas")

Mangado, X., Sánchez, M. \& Delage, C., (in press), A preliminary note on chert availability and characterization in the Kharaneh Area, Azraq Depression, Jordan. In: The Seventh World Archaeological Congress, The Dead Sea - Jordan, 2013.

Rey, M., 2010, Aproximación al estudio arqueopetrológico de la litoteca de la cuenca de la Charente (Francia). Trabajo de fin de Máster, University of Barcelona, Barcelona, 161 p. (in Spanish) ("Petroarchaeological study of the Charente Basin's Lithotheque")

Roman, D., 2010, El jaciment epimagdalenià de la Balma de la Roureda (Vilafranca, Els Ports, País Valencià). Pyrenae 41 (2): p. 7-28. (in Catalan) ("The epimagdalenian site of La Balma de la Roureda (Vilafranca, Els Ports, Valencian Country”)

Sánchez, M. \& Mangado, X., 2013, La industria lítica de Cova Alonsé. Materias primas: tipos y aprovisionamiento. In: El asentamiento magdaleniense de Cova Alonsé (Estadilla, Huesca), (Montes, L. \& Domingo, R. Eds.), Monografías Arqueológicas, Prehistoria, Vol. 48, Universidad de Zaragoza: p. 41-53. (in Spanish) ("The lithic tools from Alonsé Cave. Raw materials: types and provisioning")

Séronie-Vivien, M.-R. \& Lenoir, M., 1987, Le silex de sa genèse à l'outil. In: Cahiers du Quaternaire, n. 17 Actes du Vo colloque international sur le silex (Vth international Flint symposium), Bordeaux, 17 sept- 2 octobre 1987, Centre National de la Recherche Scientifique, Centre Régional de Publication de Bordeaux: p. 200-235. (in French) ("Chert from its genesis to a lithic tool")

Vera, J. A. (Ed.), 2004, Geología de España, Instituto Geológico y Minero de España, Sociedad Geológica de España, Madrid, 884 p. (in Spanish) (“Geology of Spain”) 